\title{
CONCEPTUAL METAPHOR OF SETYA NOVANTO'S CASE
}

\author{
Sintia Purnama1, Muhammad Akbar Nurhakim² \\ ${ }^{1}$ IKIP Siliwangi \\ ${ }^{2}$ IKIP Siliwangi \\ 1Sintia.purnam4@gmail.com, ${ }^{2}$ muhammadakbarnurhakim@gmail.com
}

\begin{abstract}
This research is entitled Conceptual Metaphors of Setya Novanto'case; In this article the author discusses the metaphor contained in news newspaper about setya novanto case. The purpose of this research is to know the meaning and function of the metaphor, this study also tries to find out the conceptualizations of politics. In this case the author uses the theory from Lakoff and Johnson .Data taken from 4 news from people's mind newspaper Tuesday 28 november 2017, Kompas daily pad Monday 20 november 2017, new compass on 22 november 2017 and people's mind on 20 november 2017 . in this research the writer use a qualitative research Method. Which all of data are they presented descriptively. From the analysis result found 4 political discourses in conceptual metaphor in the newspaper about setya novanto cases. .From 175 metaphorical statements, the researcher found 55 metaphors. that are found $45 \%$ as objects or goods that can be traded $.30 \%$ politics as a battle,10\% as a war and $15 \%$ as a race. It shows that in the political discourses, The conceptual that used by Setya novanto in building rhetoric is to compare the words in use as a comparison that is considered as objects or goods that can be traded. This strategy identifies that by using a listener metaphor will be more was impressed that the case was not considered a severe case which was considered mild and seemed difficult to resolve.
\end{abstract}

Keywords: Newspaper,Conceptual, Metaphor, Setya Novanto's case.

\section{INTRODUCTION}

Newspaper is one of the print media that aims to provide information both social and political that is happening and busy in talking even able to master the thinking of the people. The ability of such newspapers must be supported by effective language use. Not only that, there are also other factors that support the creation of good print media and to attract the attention of its readers, such as the latest news content, interesting images, the latest topics and easy-tounderstand writing.

In the current era, there are various means of print media to inform the news about political cases. One of them is a newspaper. In Indonesia itself a lot of political news that was published in the newspaper one of the news about the case setya novanto. In the case setya novanto a lot of people who offended with his involvement with the KPK because the case of E ID card which until now is still warm in talking. There are so many viewpoints of authors who claim that this novanto case contains non verbal language that makes readers tend to assume that the case of novice setya as buying and selling. With words that have different meanings or certain connotations in society and even use the meaning of the side meaning of a reference to other references, the latter is called the style of metapora language.

In the perspective of communication, the newspaper is a tool for delivering messages or information through print media from communicators to communicants. Submission of such information can be done with print media. Each community can use print media for various 
purposes such as advertising, job vacancy to inform something or provide insight into the reader against the author's perspective

According to (Syahrizal, 2016) Language phenomena toward the user has brought us to many comprehensive ideas regarding array of language usage. Literal meaning will easily create the positive interaction between speakers, but how people understand the linguistic expression such as "he attacked every weak arguments" or "I demolish his argument" (Lakoff \& Johnson, 1980). This expression has crossed mental space between two distinguished things. "Argument" in both sentence is regarded as the enemy of the subject "he" and "I" and can be attacked and demolished.

American Linguist George Lakoff and Mark Johnson in 1980 introduced conceptual metaphor. The basic concept of conceptual metaphor theory (CMT) is to oppose the idea of traditional metaphor, Lakoff and Johnson believe that metaphor is not only a form of human language, but also a matter of human action and thought. In line with that, action and thought is a fundamental role in politics, politician will act and thought not only for fulfilling their willingness but also for their people, this situation triggered the present researcher to see the conceptual metaphor in politic.

Lakoff and Johnson in Metaphor We Live By argued that in the twenty-five years since they first discovered conceptual metaphor, researchers conducted a research in fields as diverse as literary theory, legal studies, linguistics, and the philosophy of science have made (Lakoff \& Johnson, 1980) in Metaphor We Live By has strongly stated that metaphor is applied in all daily activity, since that human are thinking, conceptual metaphor will never be separated from daily life of human. Metaphor in conceptual metaphor is regarded as a fundamental cognitive competence and is unconsciously and pervasively employed in everyday life.

(Syahrizal, 2016) states that at first, the presence of conceptual metaphor is to reject the idea of substitution theory of metaphor, according to which a metaphorical expression replaces some literal expressions that have same meaning. Conceptual metaphor sees metaphor as a process of human thought in creating a meaning. Conceptual metaphor is not regarded as linguistics phenomenon but completely as human result of thinking. This kind of metaphor is used in everyday activity; this kind of metaphor is called as conventional metaphor.

Lakoff and Johnson state that conceptual metaphor is not only the linguistics phenomena but also as result of human cognition which is could help people in delivering their power in order to create a better attitudes toward certain issues.

Lakoff and Johnson state that conceptual metaphor is not only the linguistics phenomena but also as result of human cognition which is could help people in delivering their power in order to create a better attitudes toward certain issues.

Politics can be defined as all of the activities in seizing and defending power. The power of political speech is established and maintained by the powerful role of language. One of the goals of politicians is to persuade their audience of validity about their basic claims. Language can be used to influence people's political and ideological views by exploring in detail the ways in which politicians can use language for their own advantage. Persuasive political phrases must necessarily be creative by the ability to adapt the rhetorical method in order to compete for attention. 
According to (Syahrizal, 2016) Conceptual Metaphor of Politics is a core the study of metaphorical structure, in politics has bring a new conceptualization of politics itself. Politics as the fundamental element in the state has been represented trough several ideas by using metaphorical statement. This metaphoric statement brings politics into more various conceptualizations, meaning of word politics is being elevated.

In finding and discussing the data of the research, the theory from Lakoff and Johnson have been adopted. As the result of analysis, the researcher found that politics has transformed into various type of conceptualizations. From all metaphorical statement, the research categorize most common type of conceptual metaphor which represent politics in general. There are three most common conceptualizations of politics, first is POLITICS IS A RACE, second, POLITICS IS A BATTLE, and the last is POLITICS IS A WAR.

\section{METHOD}

The type of this research is descriptive qualitative because the researchers describes the linguistic form of methaphor. Qualitative research is best suited to address a research problem in which you do not know the variables and need to explore. The literature might yield little information about the phenomenon of study, and you need to learn more from participants through exploration (Creswell, 2012).

Data collection techniques that the authors use in this study is to take from the daily news newspaper compass case setya novanto cases edition November 2017. The data in use only comes from daily news newspaper compass case setya novanto. The reason the author chose this case news is because on the news there are many metaphorical meanings implied in the words conveyed by the author to the reader. therefore to narrow down the data then the authors choose case news setya novanto about cases of investigation Corruption E ID card as data. In conducting this research, the researcher follows several steps to process the data which steps they are:

Steps that the authors do in collecting data to be analyzed are as follows:

Read and sort data containing metaphor Record all data in the can Classify the metaphor of 4 news in newspaper data obtained from data collection.Categorize into 4 news data mengadung metapora with that does not contain metapora Reduce by categorizing based on words containing metapora that get and leave data that have the same word metapora with the same meaning.

The metaphor in the newspaper" To find out the presented categories of metaphor used in setya novanto's news. The percentage is determined by using the formula (Creswell, 2003);

Formula: $P=\frac{F}{N} \times 100 \%$

Explanation:

$\mathrm{P}=$ as percentage

$\mathrm{F}=$ as frequency of metaphor

$\mathrm{N}=$ as total of metaphor

\section{RESULTS AND DISCUSSION}

\section{Results}


The subject of the research is an analysis of setya novanto on newspaper with researchers, the object of research is the use of metaphor the instrumentation of this research is documentation, the documentation is saving and documenting which is taken from the observation.

In this research, the researchers found 26 metaphor in 3 article in this cases we find $45 \%$ as a thing $30 \%$ as a strategy and tactics $15 \%$ as a traading transaction $10 \%$ as a power and $0,5 \%$ as a competition. Analysis of research finding metaphor of setya novanto cases in newspaper are written.

In linguistic view of metaphor, there are three components those form a metaphor. These components are topic, vehicle and ground. The topic is the entity referred to, and the vehicle is the notion to which this entity being compared. The base in which this comparison is being made from is called the ground. (Knowles \& Moon, 2005) also identify these three components, they stated that metaphor consists of the metaphor (a word, phrase, or longer stretch of language); its meaning (what it refers to metaphorically); and the similarity or connection between the two. These three components have been referred to as vehicle, topic and ground.

\section{Discussion}

Based on the analysis we are found

1. Setya Novanto cases as a thing ( Politics is a Race )

In this part we will to explain that Setya Novanto cases as a thing that can be subtract the load.

Data 1

"Pemeriksaan saksi yang di anggap meringankan untuk setya novanto" in this sentence the writer use "meringankan" in English translation it means "alleviate" according to (Oxford dictionary) is to reduce the start time of light weight which means that we can say that Setya Novanto case as things that can reduce the burden and time and can be metaphorically as goods that have mass weight.

Data 2

"Juru bicara KPK Febri diansyah menuturkan. KPK Telah memanggil 9 saksi dan 5 Ahli yang meringankan seluruh pengajuan Novanto. Sembilan saksi itu adalah rudi alfonso,Melky lena, anwar puegeno, idrus marham, agun gunadjar, robert kardin, Aziz syamsuddin, maman abdurrohman, dan erwin siregar." In this sentence the writer use "meringankan" in English translation it means that "alleviate" according to (Oxford dictionary) alleviate reduce the start time of light weight it means we can say that Setya Novanto case as something that can reduce the burden.means this case can be metaphorically right as an object that has weight and mass

Data 3

"Staf datang ke KPK, Mengantar surat.( Idrus marham) tidak bisa datang dan minta penjadwalan ulang, sementara melky lena mengirim surat ke KPK (Menyatakan) tidak bisa datang karena ada tugas partai di luar kota" tuturnya." In this sentence the writer use "mengantar" and "mengirim" in English translation it means that "ushered in" and "send" According to (Oxford dictionary) send is to accompany And send is to convey through intermediaries means the case can be metaphorically as a good can be sent.

Data 4 
"Kami sudah ajukan, Kami engga bisa maksa kami ( nanti) kontak mereka para anggota DPR itu supaya mau jadi ahli, jadi saksi, umpamanya pak idrus, mau enggak jadi saksi, kami ajukan juga namanya, mau enggak? Itu terserah mereka." In this sentence the writer use "ahli" in English translation it means that "expert" According to (Oxford dictionary) expert is A person who is very knowledgeable about or skilful in a particular area.it means that can be methaphor as a things

\section{Data 5}

Setelah menjalani pemeriksaan aziz samsudin politikus partai golkar sekaligus anggota DPR Periode 2009-2014 dan 2014-2009 memilih tak meladeni pertanyaan wartawan." In this sentence the writer use "bungkam" in English translation it means that "mute" According to (Oxford dictionary) mute is mute Refrain from speech or while unable to say anything.means this case can be metaphorized as objects that can be hidden and in cover

Data 6

"Yang penting bagi saya adalah pentingnya kehadiran saya di KPK kedua meringankan beban psikis beliau, kalau terkait proses dan hal hal hukum lainnya. Saya pikir semuanya sudah tahu jadi biarkan hukumnya berproses seadil adilnya." Ujar dia. (ira vera tika)" In this sentence the writer use "meringankan" and "beban" in English translation it means that "alleviate" and "load" according to (Oxford dictionary) alleviate is reduce the time the beginning of the weight of a light. And "load" is A heavy or bulky thing that is being carried or is about to be carried. This case may be methaphorized as things

Data 7

Wakil sekertaris Jenderal DPP Partai golkar maman abdurrahman mengaku tak tahu alasan penunjukan dirinya sebagai salah seorang saksi meringankan.dalam kesempatan itu dia pun menegaskan tak terlibat dan tak tahu menahu soal kasus korupsi KTP elektronik." In this sentence the writer use "meringankan" in English translation it means that "alleviate" according to (Oxford dictionary) is to reduce the start time of the light weight it means we can say that Setya Novanto's case is metaphorized as something that can reduce the burden.

Data 8

"Saya tadi di panggil untuk saksi yang meringankan untuk pak setya novanto. Ada beberapa pertanyaan, tapi detailnya tidak bisa saya sebutkan satu per satu. Intinya adalah memberikan keterangan yang saya ketahui terkait pak novanto dan kasus E KTP " Tuturnya." In this sentence the writer use "meringankan" in English translation it means that "alleviate" according to (Oxford dictionary) alleviate is reduce the time the beginning of the weight of a light it means that we can says that Setya Novanto cases as a thing that can subtract the load.

Data 9

"Pemanggilan KPK itu akan menggantikan aduan dari masyarakat untuk kemudian menjadi bahan MKD menggelar rapat pergantian Novanto." In this sentence the writer use "aduan" in English translation it means that "complains" According to (Oxford dictionary) complains is a statement that something is not satisfactory or unacceptable this case in metafora kan as objects

Data 10

"Jika nama saksi si ahli yang diajukan sama dengan saat praperadilan yang lalu, tiga nama ahli ini kemungkinan besar masuk dalam daftar nama yang diajukan oleh kuasa hukum Novanto." In this sentence the writer use "diajukan" in English translation it means that "submitted" According to (Oxford dictionary) submitted is Accept or yield to a superior force 
or to the authority or will of another person. Means that this case can be metaphorized as objects that can be given

\section{Data 11}

"Wakil Ketua MKD Sarifudin Sudding mengungkapkan, terdapat dua opsi terkait dengan penggantian Novanto, yaitu lewat dan tanpa aduan masyarakat." In this sentence the writer use "aduan" in English translation it means that "complains" According to (Oxford dictionary) complains is A statement that something is unsatisfactory or unacceptable. This means the case can be metaphorized as objects that can respond to the attitude of dissatisfaction

\section{Data 12}

"Saksi dan ahli yang diajukan itu dianggap dapat meringankan Ketua DPR itu dalam menghadapi perkara korupsi pengadaan KTP elektronik." In this sentence the writer use "meringankan" in English translation it means that "alleviate" according to (Oxford dictionary) alleviate is reduce the time the beginning of the weight of a light. Means that this case can be metaphorically as an object

\section{Data 13}

"Besok (hari ini), Senin (27/11/2017), diagendakan pemeriksaan terhadap saksi dan ahli meringankan yang diajukan oleh pihak SN," ujar Juru Bicara KPK Febri Diansyah kepada "PR", Minggu (26/11/2017)." In this sentence the writer use "meringankan" in English translation it means that "alleviate" according to (Oxford dictionary) alleviate is reduce the time the beginning of the weight of a light. Means that this case can be metaphorically as an object

Data 14

"Otto Hasibuan, anggota tim kuasa hukum Novanto, menyatakan, mereka memang menggunakan hak yang tercantum di dalam Pasal 65 KUHAP." In this sentence the writer use "menggunakan" in English translation it means that "use" According to (Oxford dictionary) use is Take, hold, or deploy (something) as a means of accomplishing or achieving something; employ. as a means to achieve or achieve something; hire. this case is metaphorized as a usable item

2. Setya Novanto's cases as a Trading Transaction ( politics is a Battle )

In this part we will to explain that Setya Novanto cases as a trade and transaction and commerce.

Data 1

"Penyelidikan Kasus yang di duga melibatkan novanto tidak akan terhambat oleh sejumlah saksi yang di periksa, soalnya pemeriksaan dilakukan suturut prosedur hukum "terserah dianya mau bersaksi apa paling kami nanya nanya yang standar bagaimana pandangan dia tentang case itu" ujarnya." In this sentence the writer use "sejumlah" and "standar" in English translation it means that "any number" and "standard" According to (Oxford dictionary) "any number" is Any particular whole quantity of. And "standard" is A level of quality or attainment. According to KBBI amount is a number that is something that is collected into one and the standard is a certain measure that is used as a benchmark means this case can be interpreted as a result of numbers that have certain benchmarks such as the price of a good . and this case can be metaphorically as a trade that has certain standard

\section{Data 2}

"Dia Menuturkan saksi saksi meringankan itu merupakan anggota DPR Periode 2009-2014 mereka dinilai mengetahui proyek KTP Elektronik, Mulai dari pembahasan, penganggaran 
hingga pengadaan." In this sentence the writer use "penganggaran" and "pengadaan" in English translation it means that "budgeting" and "procurement" According to (Oxford dictionary) budgeting is an estimate of income and expenditure for a certain period of time. And "procurement" is the act of providing something. this means that this case can be metaphorized as a sale or purchase transaction or trade that generates earnings and expenses

Data 3

"Meskipun demikian menurut otto ada baiknya semua orang mengetahui ihwal proyek itu untuk bersikap kooperatif. Kami mendapat informasi dari setnov mereka,para anggota DPR tahu semuanya. Apa yang saya perbuat merka tahu semuanya" kata setnov.) tolong mereka bersaksi saja yang menguntungkan dia", ucapnya." In this sentence the writer uses" menguntungkan "in English translations to mean" favorable. "According to the (profitable dictionary of Oxford) is (business or activity) actions that bring profit or financial gain. means that this case can be metaphorized as a trading transaction

Data 4

"Tolong mereka bersaksi saja, yang menguntungkan dia," ucapnya." In this sentence the writer use "menguntungkan" in English translation it means that "profitable" According to (Oxford dictionary) profitable is (of a business or activity) yielding profit or financial gain or profit, the case is metaphorized as trading or buying and selling transactions

\section{Data 5}

"Ia mengaku telah menyerahkan semuanya ke penyidik." Saya datang berdasarkan undangan KPK Berkenaan untuk memberikan ketearangan yang menguntungkan terasngka (Novanto) makanya, ada hadir pada sore hari itu ( kemarin) "ujarnya." In this sentence the writer use "menguntungkan" in English translation it means that it means profitable means the case can be metaphorized as trading or sale and purchase transactions.

Data 6

"Meski namanya masuk sebagai saksi yang di nilai dapat menguntungkan novanto maman menyatakan sama sekali tak soal kasus korupsi pengadaan KTP Elektronik. Ia menuturkan, novanto pernah berkomunikasi dengannya dan mengaku tak terlibat dalam kasus tersebut." In this sentence the writer use "menguntungkan" in English translation it means that "profitable" According to (Oxford dictionary) profitable is (of a business or activity) yielding profit or financial gain or profit. This case may be metaphorized as trading and buying and selling transactions

3. Setya Novanto Cases a Strategy and Tactics ( Politics is a War )

In this part we will to explain that Setya Novanto cases as a strategies and tactics.

Data 1

"Pemeriksaan saksi yang di anggap meringankan untuk setya novanto tidak akan menghambat penyelidikan atas dugaan keterlibatan ketua DPR itu dalam kasus Korupsi pengadaan KTP Elektronik." In this sentences the writer use "menghambat" in English translation it means that "inhibit" According to (Oxford dictionary) inhibit is Prevent or prohibit (someone) from doing something. Inhibit is Prevent or forbid (someone) to do something. this means that the case setya novanto is interpreted as a way to weaken in order not to perform well. and in the motafora as a strategy and tactics.

Data 2 
"Meskipun demikian Ia memastikan pemeriksaan saksi yang meringankan juga tidak akan memperlambat pelimpahan berkas ke peradilan " kami sudah punya Planning” katanya." In this sentence the writer use "perencanaan" in English translation it means that "planning" According to (Oxford dictionary). Planning is the process of making a plan for something to achieve the goal efficiently and regularly means that in this case can be metaphorically as a programmed concept and has been compiled with good.

\section{Data 3}

"Seusai menjalani pemeriksaan pada pukul 15.00, ia memilih diam, tak menghiraukan berondongan pertanyaan awak media." In this sentence the writer use "berondongan" and "awak" in English translation it means that "barrage" and "crewman" According to (Oxford dictionary) barrage is A concentrated artillery bombardment over a wide area. And crewman is A member of a group of people who work on and operate a ship, aircraft, etc., particularly one who is not an officer. This means that the case is metaphorized as As a strategy or tactics a shellable item and made and arranged.

\section{Data 4}

"Fredrich Yunadi menjamin, para saksi yang diajukan itu betul-betul melihat, mendengar, dan mengetahui secara langsung ihwal proyek pengadaan KTP elektronik." In this sentence the writer use "menjamin" in English translation it means that "ensure" According to (Oxford dictionary) ensure is Make certain that (something) will occur or be the case. means this case can be metaphorized as a well-designed and promissing process

\section{Data 5}

"Febri mengatakan dari 9 saksi di jadwalkan menjalani pemeriksaan hanya dua yang hadir mereka adalah maman abdurrahman, dan Aziz syamsuddin. Pemberitahuan tidak dapat hadir dikirim oleh idrus marham dan melky lena, sementara dari ahli hanya margarito kamis yang memenuhi panggilan." In this sentence the writer use "menjalani" in English translation it means that "go through" According to (Oxford dictionary) means "through" According to (Oxford dictionary) through Search through or through a process. means this case can be interpreted as a process.

\section{Data 6}

"Seperti di beritakan, otto hasibuan anggota tim kuasa ukum novanto, berharap, para saksi itu menjelaskan duduk perkara sekaligus peran novanto di dalam kasus yang dituduhkan kepadanya." In this sentence the writer use "peran" in English translation it means that "role" According to (Oxford dictionary) role is An actor's part in the actor's inner actor means that the case can be metaphorically not as a detailed plot play

\section{Data 7}

"kami menginginkan agar saksi saksi ini di berikan kesempatan untuk menjelaskan sebenarnya peran dan fakta yang terjadi itu kayak apa sih" tuturnya di gedung KPK." In this sentence the writer use "fakta" in English translation it means that "fact" According to (Oxford dictionary) fact is a well-known fact that proves true. means that this case can be metaphorically as an event that has occurred with a clear timeline.

\section{Data 8}

"Dua diantaranya telah menjadi saksi dalam rangkaian penanganan kasus e-KTP ini," tuturnya." In this sentence the writer use "rangkaian" in English translation it means that "circuit" According to (Oxford dictionary) circuit is A roughly circular line, route, or movement 
that starts and finishes at the same place. This means the case is metaphorized as a process that has a continuous cycle spinning without meeting the end point

4. Setya Novanto cases as a Competition ( Politics is a Race )

In this part we will to explain that Setya Novanto cases as a competition, or race.

Data 1

"Wakil ketua komisi Pemberantasan korupsi saut situmorang menyatakan komisi antirasywah siap adu lihai dengan pihak Novanto." In this sentence the writer use "adu lihai" in English translation it means that "shrewd fights" According to (Oxford dictionary) shrewd fights is Having or showing sharp powers of judgement; astute. shrewd fights is Having two words which means fighting is fighting to win and shrewd has a meaning that is clever and clever and to deceive this opponent means that this case can be metaphorically as a manipulated race or game.

Data 2

"Semuanya juga begitu orang dapat memberi keterangan (untuk) membantu yang bersangkutan (Novanto) kemudain tinggal adu lihai saja sama KPK” Saut di gedung KPK." In this sentence the writer use " $a d u$ lihai" in English translation it means that "shrewd fights" According to (Oxford dictionary) shrewd fights is Having or showing sharp powers of judgement; astute. clever fights is Having two words which means fighting is fighting to win and shrewd has a meaning that is clever and clever and to deceive this opponent means that this case can be metaphorically as a manipulated race or game

5. Setya Novanto cases as a Power ( politics is a battle )

In this part we will to explain that Setya Novanto cases as a Power

Data 1

"Menurut dia KPK tidak akan membatasi siapapun yang diajukan sebagai saksi sebagai mana di beritakan tim kuasa hukum novanto mengajukan 9 saksi dan 5 ahli yang di anggap meringankan. Saut mengatakan ketrangan saksi yang meringankan novantopun tidak akan dibatasi." In this sentence the writer use "dibatasi" in English translation it means that "restricted" According to (Oxford dictionary) restricted is Limited in extent, number, scope, or action. is Limited in terms, numbers, scopes, or actions. This means that the case may be metaphorical as a power that can not be exceeded.

Data 2

"Enggak ( Dibatasi). Terserah dia ( Novanto) Mau siapa saja ( jadi saksi meringankan) iya terserah dia, mau kasih siapa (Keterangan Siapapun, kami Tulis" Ucapnya." In this sentence the writer use "dibatasi" in English translation it means that "restricted" According to (Oxford dictionary) restricted is Limited in extent, number, scope, or action. Limited in terms, numbers, scopes, or actions. This means that the case may be metaphorical as a power that can not be exceeded.

\section{Data 3}

"Saut Menuturkan KPK memberi ruang dan waktu bagi siapa pun untuk bersaksi apalagi tersangka/terdakwa memang punya hak untuk itu, sebagaimana diatur dalam pasal 65 KUHAP." In this sentence the writer use "ruang dan waktu" in English translation it means that "time-space" According to (Oxford dictionary) Time and space regarded as a single entity; specifically = "space-time". Time and space are considered as one unity; special = "spacetime". a finite cavity adjacent to the plane while time is a series of processes, tempos, probabilities of 
a state taking place, because there is a term of finite cavity assembled by a process. hence means this case can be metaphorically as a should not be exceeded.

Data 4

"Ditanya soal pelimpahan berkas kasus novanto ke pengadilan (p21) yang di nilai salah satu cara KPK tak meladeni Novanto di pra peradilan Kedua yang di jadwalkan pada 30 November 2017 nanti, saut tak mau berkomentar." In this sentence the writer use "pelimpahan" and "meladeni" in English translation it means that "delegation" and "serve" According to (Oxford dictionary) "is a set of delegates or representatives: a deputy and" serve "is a duty or service for (other people or organizations), whereas according to KBBI Delegation is the process of transferring the right of authority to someone and serve is to help prepare something that is needed then based on statement above this case can be metafhor as power and responsibility assisted in its implementation.

Data 5

"Mereka yang di panggil itu semuanya politisi partai golkar, baik yang menjabat sebagai anggota dewan atau penggurus partai "dua saksi telah pernah di periksa KPK dalam kasus e$K T P$, "Ucapnya" In this sentence the writer use "menjabat" in English translation it means that "officiate" According to (Oxford dictionary) officiate is the Act as the official responsible for something, it means the case can be metaphorically as a person's power

\section{Data 6}

Ini kan permintaan kami, ini (sifatnya) volunter namanya. Mau mereka bersaksi, silahkan enggak mau bersaksi ya enggak apa apa " tuturnya." In this sentence the writer use "permintaan" in English translation it means that "demand" According to (Oxford dictionary) is a person who is very knowledgeable or proficient in a particular field. this means that this case can be metaphorically as a job that requires people in science field.

\section{CONCLUSION}

Based on data analysis, researchers conclude that the metaphors in the newspaper news in the case of the setya novanto Based on the explanation in the chapter four, the writer comes to the conclusions as follows: From 175 metaphorical statementsThe researcher has found 55 type of conceptual metaphor use in expressing politics is orientation metaphor and ontological metaphor. The researcher found metaphorical expressions which is included into ontological metaphor,. Those data then also use to find out the conceptualization of political conceptual metaphor. It shows that in the political discourses, The conceptual that used by Setya novanto in building rhetoric is to compare the words in use as a comparison that are found $45 \%$ as objects or goods that can be traded $.30 \%$ politics as a battle, $10 \%$ as a war and $15 \%$ as a race. This strategy identifies that by using a listener metaphor will be more was impressed that the case was not considered a severe case which was considered mild and seemed difficult to resolve the use of ontological metaphor in the political discourses is used to see a different conceptual domain of politics as something more concrete or visible substances. Seeing the number of the data found in each type of conceptual metaphor, the researcher concluded that the type of conceptual metaphor that mostly used in news setya novanto'cases is Ontological metaphor.

An interesting finding concerning political conceptual metaphor was that politics has been projected into various type of domain. From the conclusion, the researcher found three common 
types of structural metaphor, those are: POLITICS IS A BATTLE, POLITICS IS A WAR, POLITICS IS A GOODS AND THINGS THAT CAN BE TRADED and POLITICS IS A RACE.

\section{ACKNOWLEDGMENTS}

Alhamdulillahirabbil'alamin, First of all, I praise to allah the almighty for bleesing and mercy given to me during my study and in completing this paper. In this accomplishing this paper. Peace and salutations are always for rosullullah SAW. During Completing the paper, the writer obtaince many help, suggestions, and motivations for many people. Therefore, in this opportuninty the writer would like express his sincere grantitude and deep respect to :

1. Dr. H Heris Hendriana, M.Pd as the head of IKIP Siliwangi Bandung

2. Drs Irma Safitri Sadikin M,Pd as the head of English Education Faculty;

3. Trisnedri Syahrizal S,pd M,Hum as supervisor for having kindly and patiently; given the writer his guidance, suggestion, valuable, advises, correction particulary in writing this papers; who has benevolently given comment, advice, motivation, and guidance in finishing this paper;

4. All lectures of english Educaton study program of IKIP Siliwangi Bandung, for their knowledge and motivation for passing the final stage of this study;

5. The staff of english education study program of IKIP Siliwangi Bandung, For their knowledge and motivation for passing the final stage of this juornal;

\section{REFERENCES}

Creswell, J. W. (2003). Research Design: Qualitative and Quantitative Approaches. London: SAGE.

Creswell, J. W. (2012). Educational Research: Planning, Conducting, and Evaluating Quantitative and Qualitative Research (4th ed.).

Knowles, \& Moon. (2005). Introducting Metaphor. London: Routledge.

Lakoff, G., \& Johnson, M. (1980). Metaphors We Live. Chicago: The University of Chicago Press.

Syahrizal, T. (2016). Political Conceptual Metaphors in Political Discourses Cognitive Semantic Study. ELTIN Journal, 4, No. 11. 